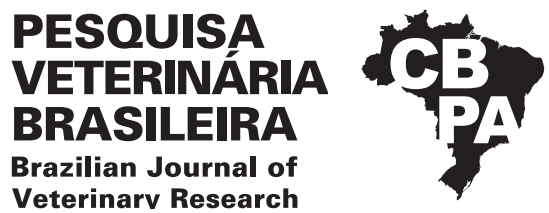

\title{
Black queen cell virus and Nosema ceranae coinfection in Africanized honey bees from southern Brazil ${ }^{1}$
}

\author{
Domitila B. Chagas ${ }^{2}$, Francielle Liz Monteiroº ${ }^{2}$ Lariane da S. Barcelos ${ }^{2}$, \\ Matheus Iuri Frühauf ${ }^{2}$ (D), Leonardo C. Ribeiro², Marcelo de Lima ${ }^{2}$, \\ Silvia de 0. Hübner ${ }^{2}$ (D) and Geferson Fischer ${ }^{2 *}$ (I)
}

\begin{abstract}
Chagas D.B., Monteiro F.L., Barcelos L.S., Frühauf M.I., Ribeiro L.C., Lima M., Hübner S. \& Fischer G. 2020. Black queen cell virus and Nosema ceranae coinfection in Africanized honey bees from southern Brazil. Pesquisa Veterinária Brasileira 40(11):892-897. Laboratório de Virologia e Imunologia, Departamento de Veterinária Preventiva, Faculdade de Veterinária, Universidade Federal de Pelotas, Campus Capão do Leão, Pelotas, RS 96010-900, Brazil. E-mail: geferson.fischer@gmail.com

Bees are fundamental in several aspects, especially in relation to plant biodiversity and pollination. Recently, immense losses are being faced in the number of Brazilian colonies, mainly in southern states of the country, which has a strong beekeeping activity. There are indications that, among the reasons for the losses, pathogens that affect the health of bees may be involved. Among them, the microsporidium Nosema and the black queen cell virus (BQCV) stand out for their prevalence. In this study, 92 colonies of 17 apiaries from southern Brazil were evaluated for infection by Nosema ceranae, Nosema apis and BQCV. Nucleic acid extractions and cDNA synthesis were performed from adult bee samples, followed by Reverse Transcription Polymerase Chain Reaction (RT-PCR) and multiplex PCR. Eight BQCV positive samples were subjected to sequencing. The results showed that $N$. ceranae and BQCV are circulating in the Southern region of the country, which may be the reason for the loss of colonies. $N$. apis was not found. N. ceranae was found in 57.6\% (53/92) of the colonies and BQCV in 32.6\% (30/92). Co-infection was found in $25 \%$ (23/92) of the colonies studied, a factor that is suggested to be reducing the hosts' longevity due to the synergistic action of the pathogens. The samples submitted to sequencing indicated similarity of 96.8 to $100 \%$ between them, in addition to strong similarity with sequences from Asia, United States, Germany and Peru. This study reports the circulation of $N$. ceranae and BQCV in apiaries in southern Brazil, in addition to being the first phylogenetic analysis of the Brazilian BQCV sequence.
\end{abstract}

INDEX TERMS: Black queen cell virus, Nosema ceranae, coinfection, Africanized honey bees, Brazil, Apis mellifera, BQCV, RT-PCR, phylogeny.

RESUMO.- [Coinfecção por vírus da realeira negra (BQCV) e Nosema ceranae em abelhas africanizadas no sul do Brasil.] As abelhas mostram-se fundamentais em diversos aspectos, especialmente com relação à biodiversidade de plantas e polinização. Recentemente, estão sendo enfrentadas imensas perdas no número de colônias brasileiras, principalmente nos estados do sul do país, com forte atividade apícola. Há indicativos de que, dentre as razões para as perdas, possam

\footnotetext{
${ }^{1}$ Received on May 26, 2020.

Accepted for publication on July 4, 2020.

${ }^{2}$ Laboratório de Virologia e Imunologia, Departamento de Veterinária Preventiva, Faculdade de Veterinária, Universidade Federal de Pelotas (UFPel), Campus Capão do Leão, Pelotas, RS 96010-900, Brazil. *Corresponding author: geferson.fischer@gmail.com
}

estar envolvidos patógenos que afetam a saúde das abelhas. Dentre eles, o microsporídio Nosema e o vírus da realeira negra (BQCV) destacam-se pela prevalência. Neste estudo, foram avaliadas 92 colônias, de 17 apiários do sul do Brasil, a respeito da infecção por Nosema ceranae, Nosema apis e BQCV. Foram realizadas extrações de ácidos nucleicos e síntese de cDNA a partir de amostras de abelhas adultas, seguidos de Reação em Cadeia da Polimerase-Transcriptase Reversa (RTPCR). Oito amostras positivas para BQCV foram submetidas a sequenciamento. Os resultados mostraram que $N$. ceranae e BQCV estão circulando na região sul do país, podendo ser a razão para as perdas de colônias. $N$. apis não foi encontrado. N. ceranae foi encontrado em 57.6\% (53/92) das colônias e BQCV em 32.6\% (30/92). Foi encontrada coinfecção por ambos 
em 25\% (23/92) das colônias estudadas, fator que sugere a diminuição da longevidade do hospedeiro por ação sinérgica dos patógenos. As amostras submetidas ao sequenciamento indicaram similaridade de 96.8 a 100\% entre elas, além de forte similaridade com sequências da Ásia, Estados Unidos, Alemanha e Peru. Este estudo relata a circulação de N. ceranae e BQCV nos apiários do sul do Brasil, além de ser a primeira análise filogenética da sequência do BQCV brasileiro.

TERMOS DE INDEXAÇÃO: Coinfecção, vírus da realeira negra, Nosema ceranae, abelhas africanizadas, Brasil, Apis mellifera, BQCV, RT-PCR, filogenia.

\section{INTRODUCTION}

The honey bee plays a vital role in world agriculture by providing pollination services to numerous wild flowering plants, there by supporting biodiversity (Allsopp et al. 2008, Smith et al. 2013). In Brazil, almost 40 thousand tons of honey are produced annually from 2.5 to 3 million hives spread throughout the national territory (Wolff et al 2018). In recent years, extensive colony losses and declining bee populations have been observed in Brazil, especially in the southern region. In three months, more than 500 million bees were found dead by beekeepers in only four Brazilian states, with Rio Grande do Sul responsible for 400 million deaths and Santa Catarina for 50 million deaths (Wolff et al 2018).

While the exact cause of colony losses remains unidentified, a growing number of evidences in various countries indicates that pathogens are associated in population declines of honey bees (Higes et al. 2008, Carreck et al. 2010). Environmental changes due to new agricultural practices and globalization may facilitate the spread of pathogens. Among the multiple pathogens infecting honey bees (Chagas et al. 2019), the microsporidia Nosema ceranae is one of the most prevalent parasite of these insects. Besides this, honey bees are also infected by several RNA viruses, and one of the most prevalent is the black queen cell virus (BQCV) (Yang et al. 2013, Porrini et al. 2016).

The microsporidian Nosema infects insects such as honey bees, bumble bees and silkworms. In honey bees has been considered one of the most serious pathogens (Higes et al. 2008). Two species can affect honey bees: $N$. ceranae, originally from Asia, and Nosema apis, which infects the Western honey bee (Fries et al. 1996). N. ceranae has been infecting Africanized A. mellifera bees in Brazil for at least the past 34 years (Teixeira et al. 2013). The Nosemosis caused by these parasites has spread worldwide and is currently responsible for considerable economic losses in apiculture (Fries 2010). The microsporidian invades the mid gut epithelial cells of the honey bees, can affect the productivity and survival of colonies (Kang et al. 1976).

The BQCV is a non-enveloped virus with a linear single positive-strand RNA genome of $9.5 \mathrm{~kb}$, belonging to the genus Triatovirus, family Dicistroviridae and to the order Picornavirales, the same order of the human hepatitis A virus (Leat et al. 2000, Spurny et al. 2017). BQCV was originally isolated in samples of decomposed queens with black spots, giving it the name of "black queen". At the initial stage of infection, larvae have a yellow appearance and a hard and rough tegument, which are clinical signs of the virus. BQCV cause mortality in queen bee pupae (Leat et al. 2000). Although only the larvae are visibly affected by this disease, adults can also be infected, but in an asymptomatic form (De Miranda et al. 2013, Muz \& Muz 2017). The transmission of BQCV occurs mainly through the fecal-oral route. It has been reported the active replication of virus in drones and the transmission through semen (Alger et al. 2019, Prodělalová et al. 2019). BQCV has already been detected in flowers collected from the apiaries (Alger et al. 2019), and in samples of honey (Milićević et al. 2018).

The BQCV and $N$. ceranae have been shown to interact synergistically in honey bee workers, with coinfection significantly decreasing host survival (Bacandritsos et al. 2010, Dainat et al. 2012, Doublet et al. 2016). In addition, an interaction was observed between $N$. ceranae and triaclopride, an insecticide, increasing individual bee mortality. Common microbial pathogens appear to be major threats to honey bees, while sublethal doses of pesticide may enhance their deleterious effects on honey bee larvae and adults (Doublet et al. 2015).

In this study, we report detection of BQCV and N. ceranae and coinfection by two agents in apiaries from southern Brazil. We also performed the first phylogenetic analysis with Brazilian sequences of BQCV.

\section{MATERIALS AND METHODS}

Sample collection. Adult bees $(\cong 30)$ were collected from 17 apiaries (92 colonies) of Apis mellifera (Africanized honey bee), located in nine municipalities of southern Brazil: Piratini/RS (31 ${ }^{\circ} 26^{\prime} 49.3^{\prime \prime} \mathrm{S}$ $\left.53^{\circ} 05^{\prime} 52.7^{\prime \prime} \mathrm{W}\right)$ - three apiaries, Arroio do Padre/RS (31 $26^{\circ} 31.7^{\prime \prime} \mathrm{S}$ $\left.52^{\circ} 25^{\prime} 22.2^{\prime \prime} \mathrm{W}\right)$ - four apiaries, São Carlos/SC $\left(27^{\circ} 05^{\prime} 00.9^{\prime \prime} \mathrm{S}\right.$ $\left.53^{\circ} 00^{\prime} 20.5^{\prime \prime} \mathrm{W}\right)$ - one apiary, Saudades/SC (26 $\left.6^{\circ} 55^{\prime} 30.7^{\prime \prime S} 53^{\circ} 00^{\prime} 17.4^{\prime \prime} \mathrm{W}\right)$ - two apiaries, Formosa do Sul/SC (26³8'49.1”S 52 47'36.2”W) - one

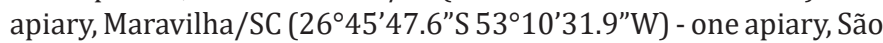
Miguel do Oeste/SC $\left(26^{\circ} 44^{\prime} 01.4^{\prime \prime} \mathrm{S} 53^{\circ} 31^{\prime} 12.0^{\prime \prime} \mathrm{W}\right)$ - two apiaries, Capão do Leão/RS (31 $\left.45^{\prime} 21.8^{\prime \prime S} 52^{\circ} 29^{\prime} 22.3^{\prime \prime W}\right)$ - one apiary, and Pelotas/RS (31³7'14.8”S 52¹8'14.8”W) - two apiaries. Samples were collected from April to October 2019. All samples were kept refrigerated during transport and immediately frozen at $-70^{\circ} \mathrm{C}$.

Nucleic acid extraction and cDNA. The total RNA was extracted from six abdomen ( $p o o l)$ of adult bees by colony using the TRIzol ${ }^{\circledR}$ Reagent (Life Technologies, Carlsbad, CA). After RNA extraction, complementary DNA (cDNA) was synthesized using iScript ${ }^{\mathrm{TM}} \mathrm{cDNA}$ Synthesis Kit (Bio-Rad). For DNA extraction the kit DNA Mini Spin (Kasvi) was used, by collecting from 100 to $200 \mu$ l of liquid of twenty abdomen ( $p o o l$ ) of adult bees by colony. This liquid was obtained by macerating 20 adult bees.

PCR and RT-PCR. The cDNA was submitted to Reverse Transcriptase Polymerase Chain Reaction (RT-PCR) assay for capsid protein gene of BQCV (Tsevegmid et al. 2016) and the DNA was submitted to multiplex PCR assay for small subunit ribosomal RNA gene of Nosema ceranae and Nosema apis (Martín-Hernández et al. 2007). All samples were tested with the endogenous control (glyceraldehyde 3-phosphate dehydrogenase - GAPDH) (Scharlaken et al. 2008) to verify the efficiency of the whole process. Primers used for amplification are described in Table 1 and PCR conditions were according to the reference. The PCR's was performed in a $25 \mu \mathrm{L}$ volume, using 100-200ng of template, 1x GoTaq ${ }^{\circledR}$ Colorless Master Mix (Promega) and $0.4 \mu \mathrm{M}$ of each primer. PCR products were resolved in a $1.5 \%$ agarose gel stained and visualized under UV light after electrophoresis (80V, 40min). Bees's pools were used as control and gBlock ${ }^{\circledR}$ Gene Fragment (Integrated DNA Technologies) was used as control of BQCV. 
Table 1. Primers used for detection of endogenous control (GAPDH), black queen cell virus (BQCV), and Nosema ceranae and Nosema apis in multiplex PCR

\begin{tabular}{cccc}
\hline Primer & Sequence $^{\text {a }}\left(5^{\prime}-3^{\prime}\right)$ & PCR product size $(\mathrm{pb})$ & Specificity \\
\hline GAPDH_F & GATGCACCCATGTTTGTTTG & 203 & GAPDH \\
GAPDH_R & TTTGCAGAAGGTGCATCAAC & & \\
BQCV_11 & AGTGGCGGAGATGTATGC & 294 & BQCV \\
BQCV_12 & GGAGGTGAAGTGGCTATATC & $218-219 \mathrm{~b}$ & N. ceranae \\
218MITOC-FOR & CGGCGACGATGTGATATGAAAATATTAA & & N. apis \\
218MITOC-REV & CCCGGTCATTCTCAAACAAAAAACCG & 321 &
\end{tabular}

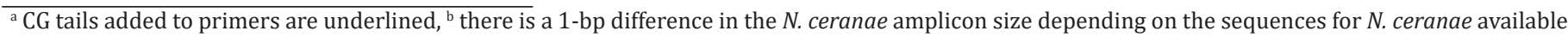
in GenBank (http://www.ncbi.nlm.nih.gov) (Martín-Hernández et al. 2007).

Sequencing analysis. One positive sample of $N$. ceranae was sequenced in duplicate using BigDye Terminator Cycle Sequencing kit (Thermo Fischer) to confirm sequences identity. Results were analyzed by the Staden program (Staden 1996) to obtain a consensus sequence from each duplicate. The alignment of sequences with those from GenBank was performed using the BioEdit version 7.0.5.3. (Hall 1999), positive samples were also sequenced. Eight samples of BQCV were sequenced in duplicate, analyzed in software's and used for phylogeny. Phylogenetic analysis was conducted by the Molecular Evolutionary Genetics Analysis (MEGA) 6.0 (Tamura et al. 2013). The evolutionary distances were inferred by using the Maximum Likelihood method based on the Kimura 2-parameter model (Kimura et al. 1980).

\section{RESULTS}

Ninety-two Africanized honey bee colonies were analyzed, covering to 17 apiaries in the southern region of Brazil. Nosema ceranae was detected in 57.6\% (53/92) and BQCV was detected in 32.6\% (30/92) of colonies, and Nosema apis was not detected in these samples. BQCV and $N$. ceranae coinfection was observed in 25\% (23/92) of colonies from this study.

Nucleotide sequences from eight positive samples of BQCV $(8 / 30)$ were analyzed and the sequences have been deposited in GenBank. The identity obtained among all samples analyzed was 96.8 to $100 \%$. In the phylogenetic analysis of partial capsid protein gene (Fig.1), the sequences of this study (BR-BQCV) showed greater similarity with Asian sequences (China, Japan, South Korea, Thailand and Mongolia) and sequences from the United States (USA), Germany and Peru. The sequence from Brazil D6 (EU292211), collected in 2007 in the Southeast region, was grouped in a different cluster when compared with the samples from this study. There was only one BQCV sequence from Brazil corresponding to the capsid protein gene deposited in GenBank and, for this reason, only this sequence was used for comparison (Teixeira et al. 2008).

\section{DISCUSSION}

We report the first survey of the occurrence of Nosema ceranae and BQCV in Africanized honey bees from southern Brazil. Our findings indicate that these two agents, that have been implicated in population declines of these insects in several countries, are widespread in populations of Africanized honey bees in southern Brazil (Ryba et al. 2012, Mendoza et al. 2013). However, the occurrence and infection profiles of $N$. ceranae and BQCV differs significantly across different counties in southern Brazil. We emphasize that, in this research, the Varroa destructor mite, which has been related to the occurrence of both BQCV and Nosema spp., was not counted.

In this study, N. ceranae was detected in 57\% (53/92) of the Africanized honey bee colonies from southern Brazil. Nosema apis was not detected in the samples. The microsporidian Nosema has been considered one of the most serious pathogens of honey bees (Higes et al. 2008), once invades the mid gut epithelial cells of the honey bees, can affect the productivity and survival of colonies (Kang et al. 1976). N. ceranae, which has been infecting Africanized A. mellifera bees in Brazil for at least the past 34 years (Teixeira et al. 2013), is considered more common and virulent than N. apis (Huang et al. 2008, Chaimanee et al. 2011), corroborating our results.

BQCV was detected in 32.6\% (30/92) of the Africanized honey bee colonies. Studies in other countries have demonstrated the high occurrence of BQCV in adult bees, $29.3 \%$ in Croatia (Gajger et al. 2014), 65\% in Australia (Roberts et al. 2017) and 25.6\% in Iran (Moharrami \& Modirrousta 2018). In Southeast Brazil, in 2007 , BQCV was detected in $37 \%$ of honey bees collected in 10 apiaries (Teixeira et al. 2008). Our results corroborate the high rates found in these places. However, differing from data commonly observed in the literature, such Shumkova et al. (2018), that detected only one case of BQCV in Bulgaria. In Argentina, only $8 \%$ of the tested samples were positive for the virus (Molineri et al. 2017). These data demonstrate that despite the high occurrence of BQCV, the presence of this virus may be lower in some regions, which reinforces the importance of specific studies in different regions of the world, especially in Brazil, where information regarding viral infections of honey bees are scarce (Teixeira et al. 2008).

Previous studies have reported the association between the BQCV with microsporidia Nosema spp., suggesting that these pathogens can act synergistically, with coinfection significantly decreasing host survival (Bacandritsos et al. 2010, Dainat et al. 2012, Doublet et al. 2015, 2016). BQCV and N. ceranae coinfection was observed in 25\% (23/92) of Africanized honey bee colonies from southern Brazil. N. ceranae is able to cause depression of the immune system which could favor the infection by viruses (Antúnez et al. 2006). Studies describe changes in the intestinal microbiota in bees infected with $N$. ceranae, with quantities being lower of Bifidobacterium and Pasteurellaceae. This result can indicate that Nosema infection could result in the reduction of these microbiota components 


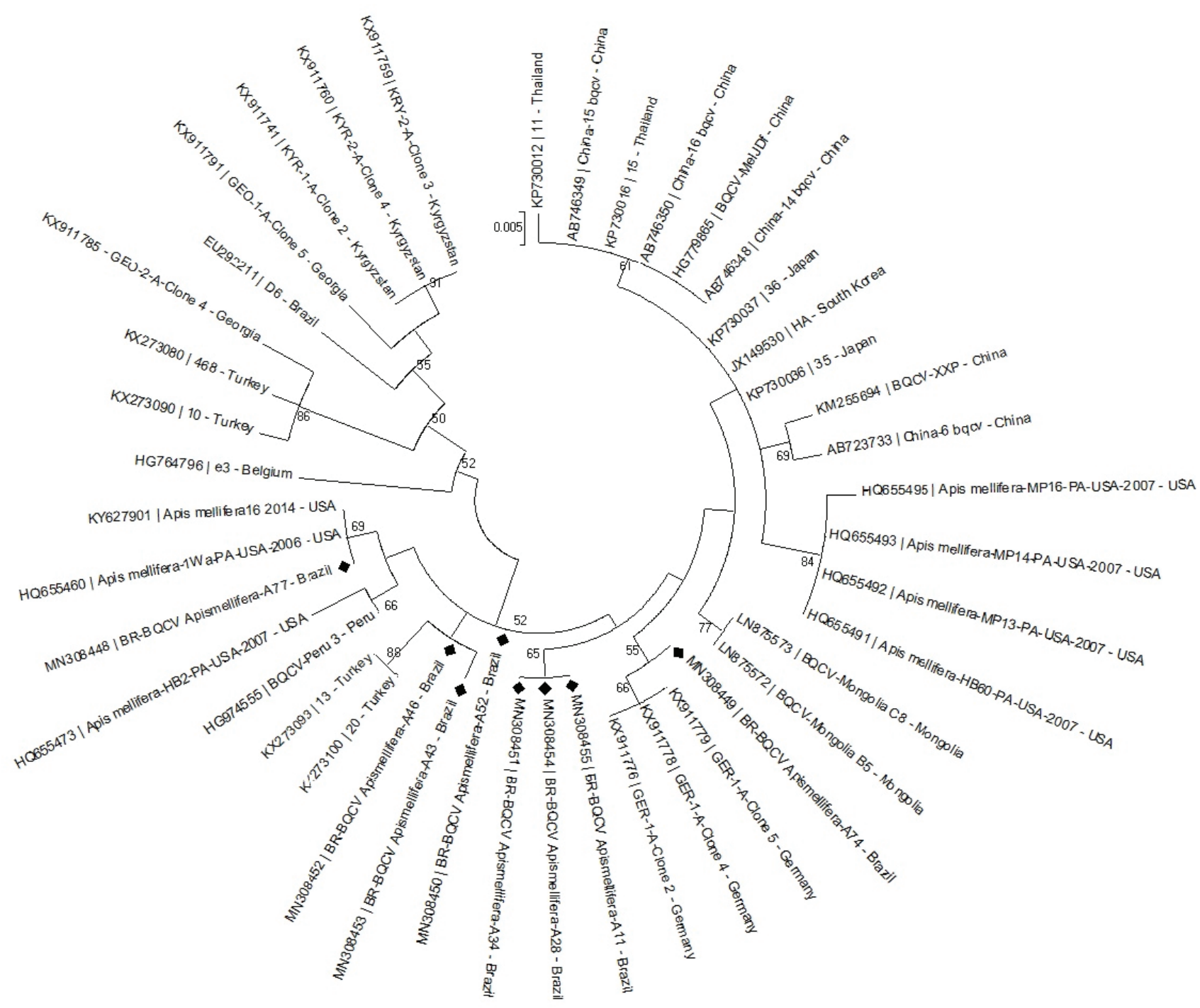

Fig.1. Phylogenetic analysis of partial capsid gene region of BQCV nucleotide sequences isolated from southern Rio Grande do Sul, Brazil. The tree was built using the Maximum Likelihood method based on the Kimura 2-parameter model and 1000 replicates bootstrap value (only node value above $50 \%$ are shown). The identified viruses are indicated by diamonds.

or conversely the microbiota composition could determine the susceptibility to infection (Li et al. 2012).

In this study, eight samples of BQCV were analyzed and deposited in GenBank (Fig.1). The sequences MN308455 (Piratini) and MN308454 (Canguçu) showed 100\% nucleotide identity, suggesting that the same virus could be circulating in both municipalities. However, the identity obtained among all samples analyzed was 96.8 to $100 \%$, also demonstrating that there are differences between viruses detected in different municipalities and within the same municipality. In the phylogenetic analysis of partial capsid protein gene (Fig.1), the sequences of this study (BR-BQCV) showed greater similarity with Asian sequences and sequences from the United States (USA), Germany and Peru. The sequences from Belgium, Kyrgyzstan and Georgia are grouped into a distinct cluster, suggesting that geographic origins of sequences can be decisive for their genetic divergence (Roberts et al. 2017, Milićević et al. 2018, Prodělalová et al. 2019). The sequence from Brazil D6 (EU292211), collected in 2007 in the Southeast region, was grouped in a different cluster when compared with the samples from this study. BQCV transmission can occur from the queen bee to its progeny (Chen et al. 2006) and, the purchase of queen bees from other places may favor the genetic diversity found in studies around Brazil.

\section{CONCLUSIONS}

The microsporidian parasite Nosema ceranae and BQCV were detected separately and in coinfections in Africanized honey bees from southern Brazil.

Although more studies are needed to determine the distribution and prevalence of Nosema and BQCV in southern Brazil, our results demonstrate that both agents are circulating in Africanized bees and may be related to the population decline of bees in the region. Also, our results include what seems to be the first phylogenetic analysis with Brazilian sequences of $\mathrm{BQCV}$. 
Acknowledgements.- We thank to "Empresa Brasileira de Pesquisa Agropecuária (Embrapa) Clima Temperado" and "Empresa de Assistência Técnica e Extensão Rural de Rio Grande do Sul” (Emater/RS) by collaboration during sample collections. F.L. Monteiro was the recipient of a PNPD/ CAPES fellowship ("Programa Nacional de Pós-Doutorado/Coordenação de Aperfeiçoamento de Pessoal de Nível Superior”).

Conflict of interest statement.- The authors declare that they have no conflict of interest.

\section{REFERENCES}

Alger S.A., Burnham A., Boncristiani H.F. \& Brody A.K. 2019. RNA virus spillover from managed honeybees (Apis mellifera) to wild bumblebees (Bombus spp.). PLoS One 14(6):e0217822.<https://dx.doi.org/10.1371/ journal.pone.0217822><PMid:31242222>

Allsopp M.H., Willem J. de L. \& Veldtman R. 2008. Valuing insect pollination services with cost of replacement. PLoS One 3(9):e3128. <https://dx.doi. org/10.1371/journal.pone.0003128>

Antúnez K., Alessandro B.D., Corbella E., Ramallo G. \& Zunino P. 2006. Honeybee viruses in Uruguay. J. Invertebr. Pathol. 93(1):67-70. <https://dx.doi.org/10.1016/j.jip.2006.05.009><PMid:16843485>

Bacandritsos N., Granato A., Budge G., Papanastasiou I., Roinioti E., Caldon M. 2010. Sudden deaths and colony population decline in Greek honey bee colonies. J. Invert. Pathol. 105(3):335-340. <https://dx.doi.org/10.1016/j. jip.2010.08.004><PMid:20804765>

Carreck N.L., Ball B.V., Martin S.J. 2010. Honey bee colony collapse and changes in viral prevalence associated with Varroa destructor. J. Apic. Res. 49(1):93-94. <https://dx.doi.org/10.3896/IBRA.1.49.1.13>

Chagas D.B., Monteiro F.L., Hübner S. de O., Lima M. \& Fischer G. 2019. Viruses that affect Apis mellifera and their occurrence in Brazil. Ciência Rural 49(9):e20181042. <https://dx.doi.org/10.1590/0103-8478cr20181042>

Chen Y.P., Pettis J.S., Collins A. \& Feldlaufer M.F. 2006. Prevalence and transmission of honeybee viruses. Appl. Environ. Microbiol. 72(1):606-611. <https://dx.doi.org/10.1128/AEM.72.1.606-611.2006><PMid:16391097>

Dainat T.B., Evans J.D., Chen Y.P., Gauthier L. \& Neumann P. 2012. Predictive markers of honey bee colony collapse. PLoS One 7(2):e32151. <https:// dx.doi.org/10.1371/journal.pone.0032151><PMid:22384162>

De Miranda J.R., Bailey B., Ball V.B., Blanchard G. \& Budge G.E. 2013. Standard methods for virus research in Apis mellifera. J. Apic. Res. 52(4):1-56. $<$ https://dx.doi.org/10.3896/IBRA.1.52.4.22>

Doublet V., Labarussias M., de Miranda J.R., Moritz R.F.A., Paxton R.J. 2015. Bees under stress: sublethal doses of a neonicotinoid pesticide and pathogens interact to elevate honey bee mortality across the life cycle. Environ. Microbiol. 17(4):969-983. <https://dx.doi.org/10.1111/14622920.12426><PMid:25611325>

Doublet V., Paxton R.J., McDonnell C.M., Dubois E., Nidelet S., Moritz R.F.A., Alaux C. \& Conte Y.L. 2016. Brain transcriptomes of honey bees (Apis mellifera) experimentally infected by two pathogens: black queen cell virus and Nosema ceranae. Genom. Data 10:79-82. <https://dx.doi.org/10.1016/j. gdata.2016.09.010> <PMid:27747157>

Fries I. 2010. Nosema ceranae in European honey bees (Apis mellifera). J. Invert. Pathol. 103(supl.):S73-S79. <https://dx.doi.org/10.1016/j.jip.2009.06.017>

Fries I., Feng F., da Silva A., Slemenda S.B. \& Pieniazek J. 1996. Nosema ceranae (Microspora, Nosematidae), morphological and molecular characterization of a microsporidian parasite of the Asian honey bee Apis cerana (Hymenoptera, Apidae). Eur. J. Protistol. 32(3):356-365. <https://dx.doi.org/10.1016/S0932-4739(96)80059-9>

Gajger I.T., Kolodziejek J., Bakonyi T. \& Nowotny N. 2014. Prevalence and distribution patterns of seven different honeybee viruses in diseased colonies: a case study from Croatia. Apidologie 45:701-706. <https:// dx.doi.org/10.1007/s13592-014-0287-0>

Hall T.A. 1999. BioEdit: a user-friendly biological sequence alignment editor and analysis program for Windows 95/98/NT. Nucleic Acids Symp. Ser. 41:95-98. <https://dx.doi.org/10.14601/Phytopathol_Mediterr-14998u1.29>

Higes M., Martín-Hernandez R., Garrido-Bailón E., GarcíaPalencia P., Meana A. 2008. Detection of infective Nosema ceranae (Microsporidia) spores in corbicular pollen of forager honeybees. J. Invert. Pathol. 97(1):76-78. <https://dx.doi.org/10.1016/j.jip.2007.06.002>

Kang Y.B., Kim D.S. \& Jang D.H. 1976. Experimental studies on the pathogenicity and developmental stages of Nosema apis, Korean. J. Vet. Res. 16:180-184.

Kimura M. 1980. A simple method for estimating evolutionary rate of base substitutions through comparative studies of nucleotide sequences. J. Mol. Evol. 16(2):111-120. <https://dx.doi.org/10.1007/BF01731581> <PMid:7463489>

Leat N., Ball N., Govan V. \& Davison S. 2000. Analysis of the complete genome sequence of black queen-cell virus, a picorna-like virus of honey bees. J. Gen. Virol. 81(Pt8):2111-2119. <https://dx.doi.org/10.1099/0022-131781-8-2111><PMid:10900051>

Li J., Chen W., Wu J., Peng W., An J., Schmid-Hempel P. \& Schmid-Hempel R. 2012. Diversity of Nosema associated with bumblebees (Bombus spp.) from China. Intern. J. Parasitol. 42(1):49-61. <https://dx.doi.org/10.1016/j. ijpara.2011.10.005>

Martín-Hernández R., Meana A., Pireto L., Salvador A.M., Garrido-Bailón E. \& Higes M. 2007. Outcome of colonization of Apis mellifera by Nosema ceranae. Appl. Environ. Microbiol. 73(20):6331-6338. <https://dx.doi. org/10.1128/AEM.00270-07><PMid:17675417>

Mendoza Y., Harriet J., Campa J., Katz H., Ramallo G., Díaz-Cetti S. \& Invernizzi C. 2013. Control de Nosema ceranae en colonias de abejas (Apis mellifera) en forestaciones de Eucalyptus grandis. Agrociência 17(1):108-113.

Milićević V., Radojičić S., Kureljušić J., Šekler M., Nešić M., Veljović L., Zorić J.M. \& Radosavljević V. 2018. Molecular detection of black queen cell virus and Kashmir bee virus in honey. AMB Expr. 8(1):128. <https://dx.doi. org/10.1186/s13568-018-0655-7><PMid:30088183>

Moharrami M. \& Modirrousta H. 2018. Molecular identification of six honeybee viruses in Iranian apiaries. Arc. Razi Inst. 73(4):311-318. <https://dx.doi. org/10.22092/ARI.2017.107481.1068><PMid:31077121>

Molineri A., Giacobino A., Pacini A., Bulacio C.A., Fondevila N., Ferrufino C., Merke J., Orellano E., Bertozzi E., Masciángelo G., Pietronave H. \& Signorini M. 2017. Risk factors for the presence of Derformed wing virus and Acute paralysis virus under temperate and subtropical climate in Argentinian bee colonies. Prev. Vet. Med. 140:106-115. <https://dx.doi.org/10.1016/j. prevetmed.2017.02.019><PMid:28460743>

Muz D. \& Muz M.N. 2017. A molecular epidemiological study of black queen cell virus in honeybees (Apis mellifera) of Turkey: the first genetic characterization and phylogenetic analysis of field viruses. Apidologie 49:89-100. <https://dx.doi.org/10.1007/s13592-017-0531-5>

Porrini C., Mutinelli F., Bortolotti L., Granato A., Laurenson L., Roberts K., Gallina A., Silvester N., Medrzycki P., Renzi T., Sgolastra F. \& Lodesani M. 2016. The status of honey bee health in Italy: results from the nationwide bee monitoring network. PLoS One 11(5):e0155411. <https://dx.doi. org/10.1371/journal.pone.0155411><PMid:27182604>

Prodělalová J., Moutelíková R. \& Titěra D. 2019. Multiple virus infections in western honeybee (Apis mellifera L.) ejaculate used for instrumental insemination. Viruses 11(4):306-314. <https://dx.doi.org/10.3390/ v11040306> <PMid:30934858>

Roberts M.K.J., Anderson D.L. \& Durr A.P. 2017. Absence of deformed wing virus and Varroa destructor in Australia provides unique perspectives on honeybee viral landscapes and colony losses. Sci. Rep. 7:1-11. <https:// dx.doi.org/10.1038/s41598-017-07290-w> 
Ryba S., Titera D., Sschodelbauero-Tramandlova I. \& Kindlamnn P. 2012. Prevalence of honeybee viruses in the Czech Republic and coinfections with other honeybee disease. Biologia 67(3):590-595. <https://dx.doi. org/10.2478/s11756-012-0038-5>

Scharlaken B., de Graaf D.C., Goossens K., Brunain M., Peelman L.J. \& Jacobs F.J. 2008. Reference gene selection for insect expression studies using quantitative real-time PCR: the head of the honeybee, Apis mellifera, after a bacterial challenge. J. Insect Sci. 8(33):1-10. <https://dx.doi. org/10.1673/031.008.3301>

Shumkova R., Neov B., Sirakova D., Georgieva A., Gadjev D., Teofanova D., Radoslavov G., Bouga M. \& Hristov P. 2018. Molecular detection and phylogenetic assessment of six honeybee viruses in Apis mellifera L. colonies in Bulgaria. PeerJ 6:e5077. <https://dx.doi.org/10.7717/peerj.5077> $<$ PMid:29942706>

Smith K.M., Loh E.H., Rostal M.K., Zambrana-Torrelio C.M., Mendiola L. \& Daszak P. 2013. Pathogens, pests, and economics: drivers of honey bee colony declines and losses. EcoHealth 10(4):434-445. <https://dx.doi. org/10.1007/s10393-013-0870-2><PMid:24496582>

Spurny R., Přidal A., Pálková L., Kiem H.K.T., de Miranda J. \& Plevkaa P. 2017. Virion structure of black queen cell virus, a common honey bee pathogen. J. Inverteb. Pathol. 91(6):e02100-16. <https://dx.doi.org/10.1128/ JVI.02100-16><PMid:28077635>

Staden R. 1996. The Staden Sequence Analysis Package. Mol. Biotechnol. 5(3):233-241.<https://dx.doi.org/10.1007/BF02900361><PMid:8837029>
Tamura K., Stecher G., Peterson D., Filipski A. \& Kumar S. 2013. MEGA6: Molecular Evolutionary Genetics Analysis version 6.0. Mol. Biol. Evol. 30(12):2725-2729. <https://dx.doi.org/10.1093/molbev/mst197> $<$ PMid:24132122>

Teixeira E.W., Chen Y., Message D., Pettis J. \& Evans D.J. 2008. Virus infection in Brazilian honey bees. J. Invertebr. Pathol. 99(1):117-119. <https:// dx.doi.org/10.1016/j. jip.2008.03.014>

Teixeira E.W., Santos L.G., Sattler A., Message D., Alves M.L.T.M.F., Martins M.F., Grassi-Stella M.L. \& Francoy T.M. 2013. Nosema ceranae has been present in Brazil for more than three decades infecting Africanized honey bees. J. Invertebr. Pathol.114(3):250-254. <https://dx.doi.org/10.1016/j. jip.2013.09.002 > <PMid:24025844>

Tsevegmid K., Neumann P. \& Yañez O. 2016. The honey bee pathosphere of Mongolia: European viruses in Central Asia. PLoS One 11(3):1-16. <https://dx.doi.org/10.1371/journal.pone.0151164><PMid:26959221>

Wolff L.F., Filipippini Alba J.M., Zanusso J. \& Ollé T. de A. 2018. Apicultura: a mortandade de abelhas e o zoneamento apícola para o Rio Grande do Sul. Embrapa Clima Temperado. 6p.

Yang B., Peng G., Li T. \& Kadowaki T. 2013. Molecular and phylogenetic characterization of honey bee viruses, Nosema microsporidia, protozoan parasites, and parasitic mites in China. Ecol. Evol.3(2):298-311.<https:// dx.doi.org/10.1002/ece3.464><PMid:23467539> 